\title{
Differences in Pulp Cell Inflammation and Dentinal Bridge Formation Between Carbonate Apatite and Calcium Hydroxide After Direct Pulp Capping on Wistar Rat Maxillary First Molar
}

\author{
Essie Octiara ${ }^{1, *}$ Melfi Zendrato $^{2}$ Endang Silalahi $^{2}$ \\ ${ }^{1}$ Department of Pediatric Dentistry, Faculty of Dentistry, Universitas Sumatera Utara, Jl. Alumni No.2 Kampus USU \\ Medan 20155 \\ ${ }^{2}$ Faculty of Dentistry, Universitas Sumatera Utara, Jl. Alumni No.2 Kampus USU Medan 20155 \\ *Corresponding author. Email: eoctiara@gmail.com
}

\begin{abstract}
Calcium hydroxide is the gold standard of dental materials used to repair exposed pulp. This research intends to observe carbonate apatite (®Gama-cha) which may be used as an alternative material in direct pulp capping treatment. The purpose of this study is to analyze the differences in pulp cell inflammation and dentinal bridge formation between carbonate apatite and calcium hydroxide after direct pulp capping was performed on the maxillary first molars of Wistar rats at 2, 4 and 6 weeks observation. The research is in post-only control group design. 60 rats were divided into 4 groups, consists of the treatment group that was given carbonate apatite (®Gama-cha) and carbonate apatite $+\mathrm{ZOE}$ group, positive control $(\mathrm{Ca}(\mathrm{OH}) 2)$ and negative control group. For every one rat, it was used 2 upper first molars, so that for each group it was performed on 30 rat's molars and filled with GIC and observed for 2, 4, and 6 weeks. The tooth selection technique was random. The results showed that inflammation decreased from 2 weeks to 6 weeks and the treatment and positive groups were not significantly different. Odontoblast cells and dentinal bridge were not formed in the 2-week study. There was no significant difference between the treatment group and the positive control group in the 4 and 6 week study for the dentinal bridge category. It can be concluded that the carbonate apatite material is quite potential in the direct pulp capping treatment.
\end{abstract}

Keywords: carbonate apatite, calcium hydroxide, pulp inflammation, dentinal bridge

\section{INTRODUCTION}

Caries is a biofilm (plaque) induced by salivarymediated acid demineralization of enamel or dentin.[1] The mechanism of caries consists of 3 theories, namely the theory of proteolysis, proteolytic-chelation, and chemoparasitic or also called an acidogenic theory. The acidogenic theory explains that the formation of dental caries is caused by acids produced by microorganisms against carbohydrates. This reaction is characterized by the decalcification of inorganic components followed by the disintegration of organic substances from the teeth.[2] According to the World Health Organization survey data in 2003 , it was found that $60-90 \%$ of children from all over the world suffer from dental caries. The highest caries prevalence occurs in America and Europe. While the lowest index occurred in Southeast Asia and
Africa.[3] According to Riskesdas data in 2013, the proportion of the population with dental and oral problems in Indonesia for the age group less than 1 year was $1.1 \%$, for the $1-4$ year age group was $10.4 \%$ and for the 5-9 year age group was $28.9 \%$. Meanwhile, the proportion of the population receiving treatment from dental medical workers for the age group less than 1 year was $36.9 \%$, for the $1-4$ year age group was $25.8 \%$ and for the 5-9 year age group was $35.1 \%$.[4] The study results in the city of Medan (Indonesia) in children aged 3 years and under found that the prevalence of ECC was $57.7 \%$ with deft of $2.17 \pm 4.49$.[5]

Research by Torres et al. in Brazil aimed to assess the incidence of enamel-dentin caries in 607 premolars and molars from 47 pediatric patients aged 10-18 years showed that 23 of them were diagnosed with enameldentin caries. In addition, this study also showed that 
enamel-dentin caries was more common in molars with a percentage of $15.12 \%$ (26 teeth).[6] Research conducted by Hutquist and Bagesund at the University of Linköping (Sweden) showed a significant correlation $(\mathrm{p}=0.002)$ between caries risk assessment at 1 year of age and the occurrence of dentinal caries at 3 years of age.[7]

One of the treatments to treat caries that has reached the dentin is pulp capping.[8] Pulp capping can be divided into indirect pulp capping and direct pulp capping.[9] Direct pulp capping is performed when the pulp is exposed due to caries, trauma, or iatrogenicity during tooth preparation or when excavating caries that have reached the dentin. [10,11] Direct pulp capping can also be performed because of untreated dentin caries so that demineralization and decalcification of the dentin extend to the pulp roof.[9]

Calcium hydroxide is a dental material that is often used because it is considered the best (gold standard) in repairing exposed pulp.[12] This material has a high $\mathrm{pH}$ (12.5-12.8) which is antibacterial and stimulates the formation of dentinal bridges.[13] The calcium ion (Ca+) inside triggers the proliferation of undifferentiated pulp cells. [14] However, this material allows for internal resorption because it can induce an inflammatory pulp response that activates preodontoblasts to differentiate into odontoclasts.[15] Research conducted by Aeinehchi $\mathrm{M}$ et al., who performed pulp capping with calcium hydroxide on 22 maxillary third molars from samples aged 20 and 25 years which were indicated for extraction, showed hyperaemia in all samples, and no odontoblast layer was formed. Necrosis was often found in almost all experimental samples. [16]

The product resulting from technology and innovation of STP UGM bone graft (®Gama-cha) which became commercial in 2014, was known to have an identical structure to human bone. This product is intended to be used as a bone substitute material to maintain space in the damaged bone, replace the lost extracellular matrix, and has identical content to the lost extracellular matrix in damaged bone and can induce new bone formation. This material is used as post-extraction area filler, jaw fracture repair, post jaw osteotomy filler, augmentation before implant placement, scaffold in bone tissue engineering and drug release systems, and accelerate wound healing in bone tissue. [17]

This product is used as a graft material that induces osteoblast cells to help the cartilage mineralization process by secreting collagen. This process is similar to forming a dentinal bridge that also begins with the induction of odontoblast cells, which will then form hard tissue deposition, which is reparative dentin $[18,19]$. A 2018 case report regarding the management of dentigerous cyst cases due to impaction of the right maxillary incisor at Dr. Sardjito Hospital used carbonate apatite (®Gama-cha) as a graft material. Autotransplantation was successful at the control at the third month after surgery. There were no signs of inflammation or mobility of teeth 11 and 12, and at the control at the fifth month after the procedure, there were no signs of inflammation or tooth mobility. patient complaints both functionally and aesthetically [20]

The content of carbonate apatite $(\mathrm{Ca} 10(\mathrm{PO} 4) 6(\mathrm{OH}) 2)$ and gelatin (the result of collagen denaturalization) makes this product considered similar to human bone structure and has good resorb and biodegradability. [21] Apatite, commonly known as hydroxyapatite (HAp), is biocompatible with the body, including human teeth, and is approximately $3-5 \%$ composed of carbonate ions. The substitution of the carbonate ion in the $\mathrm{OH}$ group is known as type A CO3Ap, while in the PO4 group is known as type B CO3Ap. Type B CO3Ap is the apatite type found in the body.[22] Considering that carbonate apatite (®Gama-cha) can induce osteoblasts, the authors are interested in conducting research using carbonate apatite (®Gama-cha), which can be used as an alternative material in direct pulp capping treatment. The purpose of this study was to analyze the differences in pulp cell inflammation and dentinal bridge formation between carbonate apatite and calcium hydroxide after direct pulp capping was performed on the maxillary first molars of Wistar rats at 2, 4, and 6 weeks of observation.

\section{MATERIALS AND METHODS}

The research design is post only control group design. The research was conducted at the University of Sumatera Utara (USU) Pharmacology Laboratory and the Anatomical Pathology Laboratory of H. Adam Malik Hospital, Medan. Ethical clearance was obtained from Health Research Ethical Committee USU with number 68/TGL/KEPK FK USU-RSUP HAM/2019. This study used 60 white male Wistar rats, body weight 200-250 grams, aged 8-9 weeks, and good health. For each Wistar rat, 2 molars were used, namely one upper right molar and one upper left first molar, then one of the molar teeth was given treatment, and the other was given control material. There were 4 experimental groups in this study; the first treatment group (30 teeth) was given carbonate apatite (®Gama-cha) then filled with GIC; the second treatment group (30 teeth) was given carbonate apatite (®Gama-cha) mixed with Zinc Oxide Eugenol (ZOE) paste (ratio 1: 5 between carbonate apatite and Zinc Oxide powder) and then were filled with GIC. The positive control group (30 teeth) was given $\mathrm{Ca}(\mathrm{OH}) 2$ paste and then were filled with GIC, and the negative control group (30 teeth) was not treated with pulp filling material, only filling with GIC material. The four experimental groups will be observed for 2 weeks, 4 , and 6 weeks. For each observation, 20 rats were killed for examination of their teeth. The tooth selection technique used in each experimental group was simple random sampling. 


\subsection{Preparation of Experimental Animal}

Experimental animals were given general anesthesia by intramuscular injection using Ketamine HCL (0.2 $\mathrm{ml} /$ injection) using $1 \mathrm{ml}$ syringe on the rat's thigh and waited for 3-4 minutes until the Wistar rat was weak. The duration of the anesthetic action of Ketamine HCL in the Wistar rats body was \pm 20 minutes. Wistar rats' mouth opening was assisted by threads tied to the upper and lower front teeth of Wistar rats. The maximum opening of the Wistar rat's mouth was $\pm 2-3 \mathrm{~cm}$.

\subsection{Preparation Procedure}

Disinfection using cotton pellet, which had been moistened with $70 \%$ alcohol. Preparation of the molars using round diamond bur in the occlusal (class I) section to the depth of the bur head $( \pm 0.5 \mathrm{~mm})$ until bleeding was visible. In the first experimental group, $20 \mathrm{mg}$ of carbonate apatite powder (®Gama-cha) was mixed with a drop of saline until the consistency came together. In the second experiment, the carbonate apatite powder was mixed with Zinc Oxide powder in a ratio of 1:5 and then mixed with eugenol until the consistency could be rolled. In both treatment groups, the cavity was filled with experimental material as much as $\pm 1 / 3$ of the cavity depth (0.15- $0.20 \mathrm{~mm})$, and the remaining $\pm 2 / 3$ of the cavity was filled with GIC.

In the positive control group, the cavity was filled with $\mathrm{Ca}(\mathrm{OH}) 2$ hard setting, the ratio of base and catalyst was $1: 1$, and then filled with GIC. In the negative control group, the cavity was immediately filled with GIC. Wistar rats were observed for 20 minutes until the rats began to regain consciousness, and then the rats were put into cages.

Rats were observed and kept in the animal house by the Pharmacology Laboratory of USU Faculty of Pharmacy. Researchers observed the condition of the mice 2-3 times a week to make sure the mice were in good health and did not die.

\subsection{Surgical Method}

The experimental animals (20 rats) at 2-week observation were killed, as well as the 4-week and 6week observations. Experimental animals were put in a closed container with cotton pile inside that had previously been moistened with chloroform. Experimental animals would die in $\pm 3-5$ minutes. Experimental animals were placed supine on paraffin. The head and the body were separated using a scalpel. Then the rat's head was skinned using scissors, and then the maxilla was separated from the head using a scalpel and scissors. The maxillary segments were washed in saline to clean blood and bacterial contamination samples. The maxillary segments were put into a container containing $10 \%$ formalin to maintain the integrity of the samples. Histomorphology was evaluated by observing the slide under the microscope with $400 \mathrm{x}$ magnification. Each slide obtained will be assigned in an appropriate score, scoring 1 being the most desirable result and scoring 4 being the least desirable result.

The data obtained were edited and tabulated. A nonparametric statistical test was performed, namely, the Kruskall-Wallis Test, because it did not meet the requirements of the Chi-Square Test with a significant degree of $95 \%$. If the results are statistically significant, a post hoc test was carried out, the Mann-Whitney test with $\alpha=0,05$ to determine which group had significant differences between the four groups of materials that had been previously tested.

\section{RESULTS}

In the observation of the type of inflammation in the study period of 2 weeks, there was no significant difference between the 10 groups of carbonate apatite, 10 groups of carbonate apatite $+\mathrm{ZOE}, 10$ groups of calcium hydroxide, and 10 groups of negative control $(\mathrm{p}=0.092)$. Unlike the study conducted for 4 weeks, a significant difference was found among the four groups ( $p=0.007$ ). The post hoc Mann-Whitney test among the four groups showed a significant difference between the carbonate apatite group and the negative control group $(p=0.015)$ and the carbonate apatite group $+\mathrm{ZOE}$ and negative control group $(\mathrm{p}=0.015)$, while in other groups, no difference was found.

For 6 weeks of observation, a significant difference was also found among the four groups $(p=0.003)$. Post hoc, which was Mann-Whitney test showed that there was a significant difference between the carbonate apatite group and negative control group $(\mathrm{p}=0.002)$, as well as the sample group that was given carbonate apatite $+\mathrm{ZOE}$ and the sample group of negative control $(p=0.009)$, and calcium hydroxide group and negative control group $(\mathrm{p}=0.009)$. (Table 1)

In the observation of the intensity of inflammation of 2 weeks period study, there was no significant difference among carbonate apatite, carbonate apatite $+\mathrm{ZOE}$, positive control, and negative control group $(\mathrm{p}=0.407)$. Unlike the case of study conducted for 4 weeks, a significant difference was found among the four groups ( $p=0.007)$. Post hoc, which was the Mann-Whitney test showed that there was a significant difference between carbonate apatite and negative group $(p=0.002)$, and carbonate apatite $+\mathrm{ZOE}$ and negative control group $(\mathrm{p}=0.009)$, as well as calcium hydroxide and negative control group $(\mathrm{p}=0.009)$. For 6 weeks of observation, a significant difference was also found among the four groups $(\mathrm{p}=0.003)$. Post hoc, which was Mann-Whitney test showed a significant difference between carbonate apatite and negative control group $(\mathrm{p}=0.002)$, as well as carbonate apatite $+\mathrm{ZOE}$ and negative control group 
Table 1. Observation Result of Inflammation Type

\begin{tabular}{|c|c|c|c|c|c|c|c|c|c|c|c|c|c|c|c|}
\hline \multirow{2}{*}{$\begin{array}{l}\text { Capping } \\
\text { Material }\end{array}$} & \multicolumn{4}{|c|}{2 weeks } & $\mathbf{p}^{(*)}$ & \multicolumn{4}{|c|}{4 weeks } & $\overline{\mathbf{p}^{(*)}}$ & \multicolumn{4}{|c|}{6 weeks } & $\mathbf{p}^{(*)}$ \\
\hline & $\begin{array}{c}\text { Scor } \\
\text { e } 1\end{array}$ & $\begin{array}{c}\text { Scor } \\
\text { e } 2\end{array}$ & $\begin{array}{c}\text { Score } \\
\mathbf{3}\end{array}$ & $\begin{array}{c}\text { Score } \\
4\end{array}$ & & $\begin{array}{c}\text { Score } \\
1\end{array}$ & $\begin{array}{c}\text { Score } \\
2\end{array}$ & $\begin{array}{c}\text { Score } \\
\mathbf{3}\end{array}$ & $\begin{array}{c}\text { Score } \\
4\end{array}$ & & $\begin{array}{c}\text { Score } \\
1\end{array}$ & $\begin{array}{c}\text { Score } \\
2\end{array}$ & $\begin{array}{c}\text { Score } \\
3\end{array}$ & $\begin{array}{c}\text { Score } \\
4\end{array}$ & \\
\hline $\begin{array}{l}\text { Carbonate } \\
\text { Apatite }\end{array}$ & 3 & 4 & 3 & 0 & & 9 & 1 & 0 & 0 & & 9 & 1 & 0 & 0 & \\
\hline $\begin{array}{c}\text { Carbonate } \\
\text { Apatite + } \\
\text { ZOE }\end{array}$ & 0 & 8 & 2 & 0 & 0,092 & 9 & 1 & 0 & 0 & $\mathbf{0 , 0 0 7}$ & 8 & 2 & 0 & 0 & 0,003 \\
\hline $\begin{array}{l}\text { Positive } \\
\text { Control }\end{array}$ & 1 & 6 & 3 & 0 & & 7 & 3 & 0 & 0 & & 8 & 2 & 0 & 0 & \\
\hline $\begin{array}{l}\text { Negative } \\
\text { Control }\end{array}$ & 0 & 3 & 7 & 0 & & 3 & 5 & 2 & 0 & & 2 & 8 & 0 & 0 & \\
\hline
\end{tabular}

Desc: Score 1= No inflammation; Score 2= chronic inflammation (non-granular inflammatory cells); Score 3= acute and chronic inflammation; Score $4=$ acute inflammation (granular inflammatory cells). (*) using Kruskal Wallis test with $\alpha=0,05$

Table 2. Observation Result of Inflammation Intensity

\begin{tabular}{|c|c|c|c|c|c|c|c|c|c|c|c|c|c|c|c|}
\hline \multirow{2}{*}{$\begin{array}{l}\text { Capping } \\
\text { Material }\end{array}$} & \multicolumn{4}{|c|}{2 weeks } & $\mathbf{p}^{(*)}$ & \multicolumn{4}{|c|}{4 weeks } & $\mathbf{p}^{(*)}$ & \multicolumn{4}{|c|}{ 6 weeks } & $\mathbf{p}^{(*)}$ \\
\hline & $\begin{array}{c}\text { Score } \\
1\end{array}$ & $\begin{array}{c}\text { Score } \\
2\end{array}$ & $\begin{array}{c}\text { Score } \\
3\end{array}$ & $\begin{array}{c}\text { Score } \\
4\end{array}$ & & $\begin{array}{c}\text { Score } \\
1\end{array}$ & $\begin{array}{c}\text { Score } \\
2\end{array}$ & $\begin{array}{c}\text { Score } \\
3\end{array}$ & $\begin{array}{c}\text { Score } \\
4\end{array}$ & & $\begin{array}{c}\text { Score } \\
1\end{array}$ & $\begin{array}{c}\text { Score } \\
2\end{array}$ & $\begin{array}{c}\text { Score } \\
3\end{array}$ & $\begin{array}{c}\text { Score } \\
4\end{array}$ & \\
\hline $\begin{array}{c}\text { Carbonate } \\
\text { Apatite }\end{array}$ & 3 & 4 & 3 & 0 & & 9 & 1 & 0 & 0 & & 9 & 1 & 0 & 0 & \\
\hline $\begin{array}{c}\text { Carbonate } \\
\text { Apatite + } \\
\text { ZOE }\end{array}$ & 0 & 5 & 5 & 0 & 0,407 & 9 & 1 & 0 & 0 & 0,007 & 8 & 2 & 0 & 0 & $\mathbf{0 , 0 0 3}$ \\
\hline $\begin{array}{l}\text { Positive } \\
\text { Control }\end{array}$ & 1 & 6 & 3 & 0 & & 7 & 3 & 0 & 0 & & 8 & 2 & 0 & 0 & \\
\hline $\begin{array}{c}\text { Negative } \\
\text { Control }\end{array}$ & 0 & 6 & 4 & 0 & & 3 & 5 & 2 & 0 & & 2 & 8 & 0 & 0 & \\
\hline
\end{tabular}

Desc: Score 1= no or very few inflammatory cells were found; Score $2=$ mild (mean number of inflammatory cells $<10$ ); Score $3=$ moderate (mean number of inflammatory cells $10-25$ ); Score $4=$ severe (mean number of inflammatory cells $>25$ ). (*) using Kruskal Wallis test with $\alpha=0,05$.

( $\mathrm{p}=0.009)$, as well as calcium hydroxide and negative control group ( $\mathrm{p}=0.009)$. (Table 2$)$

In the observation of inflammation expansion within the 2-week study period, it was found that there was a significant difference $(\mathrm{p}=0.012)$ among carbonate apatite, carbonate apatite $+\mathrm{ZOE}$, calcium hydroxide, and negative control. Post hoc which was Mann-Whitney test among the four groups showed a significant difference between the carbonate apatite and negative control group $(\mathrm{p}=0.002)$ and between the groups of carbonate apatite + ZOE with negative control group ( $\mathrm{p}=0.013)$. In 4-week observation, there was a significant difference $(\mathrm{p}=0.007)$ among the four groups. The Mann-Whitney test showed significant results between carbonate apatite and negative control group $(\mathrm{p}=0.007)$ and between carbonate apatite + $\mathrm{ZOE}$ and negative control group ( $\mathrm{p}=0.007)$. In 6 weeks of observation, it was found that there was a significant difference ( $\mathrm{p}=0.003$ ) among the four groups. The Mann-
Whitney test showed that there was a significant difference between carbonate apatite and negative control group $(\mathrm{p}=0.002)$, carbonate apatite $+\mathrm{ZOE}$, and negative control group $(\mathrm{p}=0.009)$, and between calcium hydroxide and negative control group $(\mathrm{p}=0.009)$. (Table 3)

Observation of odontoblast cell layers within 2 weeks study showed no odontoblast cell layers were formed among the four groups. During 4 weeks of observation, there was no significant difference ( $\mathrm{p}=0.098$ ) among the four groups. It was similar to the observation for 6 weeks, which was no significant difference found $(\mathrm{p}=0.11)$ among the four groups. (Table 4)

In the observation of dentinal bridge continuity within 2 weeks study, no dentinal bridges were found from the four groups. A significant difference was found between the four groups during 4 weeks of observation $(p=0,023)$. 
Table 3. Observation Result of Inflammation Expansion

\begin{tabular}{|c|c|c|c|c|c|c|c|c|c|c|c|c|c|c|c|}
\hline \multirow{2}{*}{$\begin{array}{l}\text { Capping } \\
\text { Material }\end{array}$} & \multicolumn{4}{|c|}{2 weeks } & $\overline{\mathbf{p}^{(*)}}$ & \multicolumn{4}{|c|}{4 weeks } & $\overline{\mathbf{p}^{(*)}}$ & \multicolumn{4}{|c|}{6 weeks } & $\overline{\mathbf{p}}^{(*)}$ \\
\hline & $\begin{array}{c}\text { Score } \\
1\end{array}$ & $\begin{array}{c}\text { Score } \\
2\end{array}$ & $\begin{array}{c}\text { Score } \\
3\end{array}$ & $\begin{array}{c}\text { Score } \\
4\end{array}$ & & $\begin{array}{c}\text { Scor } \\
\text { e } 1\end{array}$ & $\begin{array}{c}\text { Score } \\
2\end{array}$ & $\begin{array}{c}\text { Score } \\
3\end{array}$ & $\begin{array}{c}\text { Score } \\
4\end{array}$ & & $\begin{array}{c}\text { Score } \\
1\end{array}$ & $\begin{array}{c}\text { Score } \\
2\end{array}$ & $\begin{array}{c}\text { Score } \\
3\end{array}$ & $\begin{array}{c}\text { Score } \\
4\end{array}$ & \\
\hline $\begin{array}{c}\text { Carbonate } \\
\text { Apatite }\end{array}$ & 3 & 4 & 3 & 0 & & 9 & 1 & 0 & 0 & & 9 & 1 & 0 & 0 & \\
\hline $\begin{array}{c}\text { Carbonate } \\
\text { Apatite + } \\
\text { ZOE }\end{array}$ & 0 & 5 & 5 & 0 & 0,012 & 9 & 1 & 0 & 0 & $\mathbf{0 , 0 0 7}$ & 8 & 2 & 0 & 0 & $\mathbf{0 , 0 0 3}$ \\
\hline $\begin{array}{l}\text { Positive } \\
\text { Control }\end{array}$ & 1 & 5 & 4 & 0 & & 7 & 3 & 0 & 0 & & 8 & 2 & 0 & 0 & \\
\hline $\begin{array}{l}\text { Negative } \\
\text { Control }\end{array}$ & 0 & 1 & 7 & 2 & & 3 & 5 & 2 & 0 & & 2 & 8 & 0 & 0 & \\
\hline
\end{tabular}

Desc: Score 1= no expansion of inflammation; Score 2= mild (inflammatory cells present only close to the pulp exposure area/dentinal bridge); Score $3=$ moderate (inflammatory cells found in $1 / 3$ or more of the roof of the pulp to the middle of the pulp); Score $4=$ severe (all pulp infiltrated by inflammatory cells/pulp necrosis). $(*)$ using Kruskal Wallis test with $\alpha=0,05$.

Table 4. Observation Result of odontoblast cell layer

\begin{tabular}{|c|c|c|c|c|c|c|c|c|c|c|c|c|c|c|c|}
\hline \multirow{3}{*}{$\begin{array}{l}\text { Capping } \\
\text { Material }\end{array}$} & \multicolumn{4}{|c|}{2 weeks } & $\mathbf{p}^{(*)}$ & \multicolumn{4}{|c|}{4 weeks } & $\mathbf{p}^{(*)}$ & \multicolumn{4}{|c|}{6 weeks } & $\mathbf{p}^{(*)}$ \\
\hline & Score & Score & Score & Score & & Score & Score & Score & Score & & Score & Score & Score & Score & \\
\hline & & 2 & 3 & 4 & & 1 & 2 & 3 & 4 & & 1 & & & & \\
\hline $\begin{array}{c}\text { Carbonate } \\
\text { Apatite }\end{array}$ & 0 & 0 & 0 & 0 & & 6 & 4 & 0 & 0 & & 2 & 7 & 1 & 0 & \\
\hline $\begin{array}{c}\text { Carbonate } \\
\text { Apatite + } \\
\text { ZOE }\end{array}$ & 0 & 0 & 0 & 0 & - & 8 & 2 & 0 & 0 & 0,098 & 3 & 7 & 0 & 0 & 0,011 \\
\hline $\begin{array}{l}\text { Positive } \\
\text { Control }\end{array}$ & 0 & 0 & 0 & 0 & & 7 & 2 & 1 & 0 & & 2 & 8 & 0 & 0 & \\
\hline $\begin{array}{c}\text { Negative } \\
\text { Control }\end{array}$ & 0 & 0 & 0 & 0 & & 3 & 5 & 2 & 0 & & 1 & 5 & 4 & 0 & \\
\hline
\end{tabular}

Desc: Score 1: there are odontoblast cells that are neatly arranged / palisade; Score 2: the presence of odontoblasts cells and odontoblast-like cells; Score 3: only odontoblast-like cell; Score 4: odontoblast cells were not formed. $(*)$ using Kruskal Wallis test with $\alpha=0,05$.

The Mann-Whitney test showed a significant difference between carbonate apatite + ZOE and negative control group $(\mathrm{p}=0.007)$ and between calcium hydroxide and negative control group $(\mathrm{p}=0.042)$. During 6 weeks of observation, there was a significant difference among the four groups $(\mathrm{p}=0.026)$. The Mann-Whitney test showed a significant difference between carbonate apatite and negative control group $(\mathrm{p}=0.021)$, between carbonate apatite $+\mathrm{ZOE}$ and negative control group $(\mathrm{p}=0.010)$, and between calcium hydroxide and negative control group $(\mathrm{p}=0.021)$. (Table 5)

In observing the morphology of dentinal bridge within 2 weeks study, there was no dentinal bridge formed from the four samples. During 4 weeks of observation, there was a significant difference $(p=0.005)$ among the four sample groups. Post hoc Mann-Whitney test showed significant difference $(\mathrm{p}=0.029)$ between group given carbonate apatite and negative control group, between carbonate apatite $+\mathrm{ZOE}$ and negative control group $(\mathrm{p}=0.029)$, and between calcium hydroxide and negative control group $(\mathrm{p}=0.029)$. In 6-week observation, there was a significant difference $(\mathrm{p}=0.004)$ among the four sample groups. The Mann-Whitney test showed a significant difference between the carbonate apatite group and negative control group $(\mathrm{p}=0.007)$, between the carbonate apatite $+\mathrm{ZOE}$ group and negative control 
Table 5. Observation Result of Dentinal Bridge Continuity

\begin{tabular}{|c|c|c|c|c|c|c|c|c|c|c|c|c|c|c|c|}
\hline \multirow{2}{*}{$\begin{array}{l}\text { Capping } \\
\text { Material }\end{array}$} & \multicolumn{4}{|c|}{2 weeks } & $\mathrm{p}^{(*)}$ & \multicolumn{4}{|c|}{4 weeks } & $\mathrm{p}^{(*)}$ & \multicolumn{4}{|c|}{6 weeks } & $\mathrm{p}^{(*)}$ \\
\hline & $\begin{array}{c}\text { Score } \\
1\end{array}$ & $\begin{array}{c}\text { Score } \\
2\end{array}$ & $\begin{array}{c}\text { Score } \\
3\end{array}$ & $\begin{array}{c}\text { Score } \\
4\end{array}$ & & $\begin{array}{c}\text { Score } \\
1\end{array}$ & $\begin{array}{c}\text { Score } \\
2\end{array}$ & $\begin{array}{c}\text { Score } \\
3\end{array}$ & $\begin{array}{c}\text { Score } \\
4\end{array}$ & & $\begin{array}{c}\text { Score } \\
1\end{array}$ & $\begin{array}{c}\text { Score } \\
2\end{array}$ & $\begin{array}{c}\text { Score } \\
3\end{array}$ & $\begin{array}{c}\text { Score } \\
4\end{array}$ & \\
\hline $\begin{array}{l}\text { Carbonate } \\
\text { Apatite }\end{array}$ & - & - & - & - & & 6 & 4 & 0 & 0 & & 5 & 5 & 0 & 0 & \\
\hline $\begin{array}{c}\text { Carbonate } \\
\text { Apatite + ZOE }\end{array}$ & - & - & - & - & - & 9 & 1 & 0 & 0 & 0,023 & 6 & 4 & 0 & 0 & 0,026 \\
\hline $\begin{array}{l}\text { Positive } \\
\text { Control }\end{array}$ & - & - & - & - & & 7 & 3 & 0 & 0 & & 5 & 5 & 0 & 0 & \\
\hline $\begin{array}{l}\text { Negative } \\
\text { Control }\end{array}$ & - & - & - & - & & 3 & 4 & 3 & 0 & & 1 & 6 & 3 & 0 & \\
\hline
\end{tabular}

Desc: Score 1: the dentinal bridge is completely formed; Score 2: dentinal bridge has formed covering more than half of the exposed area; Score 3: dentinal bridge initiation has been formed which has not covered half of the exposure area; Score 4: no dentinal bridge. (*) using Kruskal Wallis test with $\alpha=0,05$

Table 6. Observation Result of Dentinal Bridge Morphology

\begin{tabular}{|c|c|c|c|c|c|c|c|c|c|c|c|c|c|c|c|}
\hline \multirow{2}{*}{$\begin{array}{l}\text { Capping } \\
\text { Material }\end{array}$} & \multicolumn{4}{|c|}{2 weeks } & $\mathrm{p}^{(*)}$ & \multicolumn{4}{|c|}{4 weeks } & $\mathrm{p}^{(*)}$ & \multicolumn{4}{|c|}{6 weeks } & $\mathrm{p}^{(*)}$ \\
\hline & $\begin{array}{c}\text { Score } \\
1\end{array}$ & $\begin{array}{c}\text { Score } \\
2\end{array}$ & $\begin{array}{c}\text { Score } \\
3\end{array}$ & $\begin{array}{c}\text { Score } \\
4\end{array}$ & & $\begin{array}{c}\text { Score } \\
1\end{array}$ & $\begin{array}{c}\text { Score } \\
2\end{array}$ & $\begin{array}{c}\text { Score } \\
3\end{array}$ & $\begin{array}{c}\text { Score } \\
4\end{array}$ & & $\begin{array}{c}\text { Score } \\
1\end{array}$ & $\begin{array}{c}\text { Score } \\
2\end{array}$ & $\begin{array}{c}\text { Score } \\
3\end{array}$ & $\begin{array}{c}\text { Score } \\
4\end{array}$ & \\
\hline $\begin{array}{l}\text { Carbonate } \\
\text { Apatite }\end{array}$ & 0 & 0 & 0 & 0 & & 0 & 10 & 0 & 0 & & 2 & 8 & 0 & 0 & \\
\hline $\begin{array}{c}\text { Carbonate } \\
\text { Apatite + } \\
\text { ZOE }\end{array}$ & 0 & 0 & 0 & 0 & _- & 0 & 10 & 0 & 0 & 0,005 & 1 & 9 & 0 & 0 & 0,004 \\
\hline $\begin{array}{l}\text { Positive } \\
\text { Control }\end{array}$ & 0 & 0 & 0 & 0 & & 0 & 10 & 0 & 0 & & 2 & 8 & 0 & 0 & \\
\hline $\begin{array}{c}\text { Negative } \\
\text { Control }\end{array}$ & 0 & 0 & 0 & 0 & & 0 & 6 & 4 & 0 & & 0 & 5 & 5 & 0 & \\
\hline
\end{tabular}

Desc: Score 1: dentin was completely formed; Score 2: only irregular hard tissue deposition is formed; Score 3: only thin layer of hard tissue deposition is formed; Score 4 : no hard tissue deposition. (*) using Kruskal Wallis test with $\alpha=0,05$.

group $(\mathrm{p}=0.010)$ and between the calcium hydroxide group and negative control group $(\mathrm{p}=0.007)$. (table 6$)$. In the observation of the thickness of the dentinal bridge within 2 weeks study, no dentinal bridge was found from the four groups. A significant difference was found between the four groups during 4 weeks of observation $(\mathrm{p}=0.048)$. Mann-Whitney test result showed a significant difference between carbonate apatite $+\mathrm{ZOE}$ and negative control group $(\mathrm{p}=0.008)$. In 6 weeks of observation, there was a significant difference among the four groups $(p=0.0001)$. Mann-Whitney test result showed a significant difference between carbonate apatite and negative control group $(\mathrm{p}=0.0001)$, between carbonate apatite $+\mathrm{ZOE}$ and negative control group $(\mathrm{p}=0.0001)$, and between calcium hydroxide and negative control group. $(\mathrm{p}=0.013)$. (Table 7)

Table 7. Observation Result of Dentinal Bridge Thickness

\begin{tabular}{|c|c|c|c|c|c|c|c|c|c|c|c|c|c|c|c|}
\hline \multirow{2}{*}{$\begin{array}{l}\text { Capping } \\
\text { Material }\end{array}$} & \multicolumn{4}{|c|}{2 weeks } & $\mathrm{p}^{\mathrm{j}^{(*)}}$ & \multicolumn{4}{|c|}{4 weeks } & $\mathrm{p}^{(*)}$ & \multicolumn{4}{|c|}{6 weeks } & $\mathrm{p}^{(*)}$ \\
\hline & $\begin{array}{c}\text { Score } \\
1\end{array}$ & $\begin{array}{c}\text { Score } \\
2\end{array}$ & $\begin{array}{c}\text { Score } \\
3\end{array}$ & $\begin{array}{c}\text { Score } \\
4\end{array}$ & & $\begin{array}{c}\text { Score } \\
1\end{array}$ & $\begin{array}{c}\text { Score } \\
2\end{array}$ & $\begin{array}{c}\text { Score } \\
3\end{array}$ & $\begin{array}{c}\text { Score } \\
4\end{array}$ & & $\begin{array}{c}\text { Score } \\
1\end{array}$ & $\begin{array}{c}\text { Score } \\
2\end{array}$ & $\begin{array}{c}\text { Score } \\
3\end{array}$ & $\begin{array}{c}\text { Score } \\
4\end{array}$ & \\
\hline $\begin{array}{l}\text { Carbonate } \\
\text { Apatite }\end{array}$ & 0 & 0 & 0 & 0 & & 5 & 4 & 1 & 0 & & 1 & 8 & 1 & 0 & \\
\hline $\begin{array}{c}\text { Carbonate } \\
\text { Apatite + } \\
\text { ZOE }\end{array}$ & 0 & 0 & 0 & 0 & - & 7 & 3 & 0 & 0 & 0,048 & 4 & 5 & 1 & 0 & 0,0001 \\
\hline $\begin{array}{l}\text { Positive } \\
\text { Control }\end{array}$ & 0 & 0 & 0 & 0 & & 5 & 3 & 2 & 0 & & 2 & 3 & 5 & 0 & \\
\hline $\begin{array}{c}\text { Negative } \\
\text { Control }\end{array}$ & 0 & 0 & 0 & 0 & & 2 & 3 & 5 & 0 & & 0 & 0 & 10 & 0 & \\
\hline
\end{tabular}

Desc: Score 1: >0,25mm; Score 2: 0,1-0,25mm; Score 3: <0,1 mm; Score 4: no dentinal bridge.

(*) using Kruskal Wallis test with $\alpha=0,05$ 


\section{DISCUSSION}

Comparison of dentinal bridge formation between carbonate apatite and calcium hydroxide as direct pulp capping material in this study used Wistar rats as experimental animals. Many studies have used rats in dentistry to evaluate direct pulp capping and pulpotomy and the healing reaction after pulp exposure. The histological pulp healing process after direct pulp capping using calcium hydroxide showed identical results in rats and humans. The molar teeth of rats are anatomically, histologically, biologically, and physiologically similar to human teeth but are smaller in size. The rat molars are also showed the same structural characteristics as human molars, in the pulp chamber, pulp tissue, and apical delta with minor apical foramen.[23,24]

In the beginning of pulp inflammation, there will be vasodilation and increased blood flow, and this is due to inflammatory factors present in the area of irritation. Pulp areas close to irritation will have the most severe inflammatory manifestations that will cause vascular response, whereas areas around and far from irritation will have mild or no inflammation.[25] Over a 2-week period (Table 1 and 2), it showed that the acute inflammation had subsided in all groups. There was no difference among the four groups in the type and intensity of inflammation. In the extent of inflammation (Table 3), it was found that 2 teeth had severe inflammatory expansion (all pulps were inflamed by inflammatory cells) in the negative group, while it was not found in the other 3 groups. In the carbonate apatite group, 3 teeth did not experience the expansion of inflammation, while in the positive control group, there was found 1 tooth, and in the carbonate apatite $+\mathrm{ZOE}$ group and the negative control, there were not found. Here the carbonate apatite material is quite effective in limiting the expansion of inflammation that occurs after pulp capping, although statistically no differences were found among the apatite carbonate, apatite carbonate, and calcium hydroxide groups.

After 4 and 6 weeks, it was found that the carbonate apatite, carbonate apatite $+\mathrm{ZOE}$, and calcium hydroxide groups had better results on the type of inflammation, the intensity of inflammation, and extent of inflammation compared to the negative group (Tables 1,2 and 3). When compared among the 3 groups, it was found that there was no difference in results between the two experimental groups and the positive group. However, it was found that more teeth were not inflamed, more teeth that did not have inflammatory cells and more teeth that did not have inflammation expansion in the carbonate apatite group compared to the positive control group.

On average, there was a decrease in chronic inflammation scores among the three groups (beside the negative control group) for 2, 4, and 6 weeks. Regarding the extent of inflammation, in the 4 and 6-week studies, more teeth did not experience inflammation extension. The score of mild inflammation extension also decreased among the three groups compared to the negative group.

The study by Zakaria et al. evaluated the carbonate apatite cement in inducing reparative dentin in the exposed dental pulp (after 3 weeks of pulp capping treatment), which histologically resulted in no signs of chronic inflammation or pulp necrosis. [22] After 30 days, chronic inflammatory cell infiltration was found near the exposed area or hard tissue formed and between the two materials did not show statistically significant differences. Another study by Fatimatuzzahro et al on the inflammatory response of the dental pulp of Sprague Dawley rats after application of the material etching of ethylene diamine tetraacetic acid and formic acid 37\% which on the 14th day after treatment, showed less inflammatory cell infiltration than the previous days and gave normal pulp appearance. The decrease in inflammatory cells indicates that immune cells have succeeded in removing cellular debris so that inflammation does not continue. This may occur because $\mathrm{OH}$ - ions released by carbonate apatite and calcium hydroxide will eliminate and irritate bacteria by destroying the cytoplasmic membrane and denaturing bacterial proteins.[26]

Based on the research by Sabir et al. who examined the inflammatory response in the pulp tissue after pulp capping using EPP (Ethanol Propolis Extract) material said that on the 14th day after treatment, the number of inflammatory cell infiltration was less than the previous days and gave an overview of the normal pulp tissue.[27] This indicates that immune cells have succeeded in removing irritants and cellular debris so that inflammation does not continue. In addition, the pulp dentin complex has a self-protection mechanism to limit the penetration of materials that harm the pulp. Calcium ions, phosphate and fluid, were contained in the dentinal tubules. This is in accordance with the study results in Tables 1,2,3 which showed that in each treatment group after 4 weeks, there were few inflammatory cells, even to the point that there were no visible inflammatory cells. Differences in inflammatory cells formed may occur due to differences in direct pulp capping materials given during the study.

Based on Salah et.al research using carbonate apatite in bone formation, $80-90 \%$ of neutrophil and lymphocyte cell infiltration occurred in the second week of the study, and $10 \%$ of immature bone tissue was formed.[28] The results of this study are in line with research by Park et al., which stated that in the second week, there was an infiltration of neutrophil and lymphocytes cells, and loose connective tissue was formed. Also, in line with another research who used hydroxyapatite and chitosan fibroin treatment, reported the formation of immature bone (woven bone) in the second week[29]. This shows 
that carbonate apatite can reduce inflammatory cells in bone formation and reduce inflammatory cells in dentinal bridge formation. In accordance with table 1,2,3, which shows that most of the samples using carbonate apatite were no longer have inflammatory cells so there was also no expansion of inflammatory cells into the pulp. This is in accordance with Salah's study that carbonate apatite has the ability to reduce inflamed cells because carbonate apatite is alkaline.[28]

The study results in table 4 show that there was no odontoblast cell layer formed from the four samples in the 2-week study. New odontoblast cells were formed in 4 and 6 weeks study, although there was still no significant difference among the four sample groups. Odontoblast cells and odontoblast-like cells appeared more in the 6-week study, both in the group given carbonate apatite alone and in the group given carbonate apatite + ZOE. This may be due to the non-toxic nature of carbonate apatite so that it has good adaptation to odontoblast cells. Odontoblast-like cells found may be correlated to the preparation procedure, where in pulp damage such as mechanical (iatrogenic) trauma, the primary odontoblast cells will be damaged. [30]

The results of the study in tables 5, 6, and 7 showed that no dentinal bridge was formed in the 2-week study. In the 4 and 6 week study, there were significant differences among the four sample groups regarding the dentinal bridge's continuity, morphology, and thickness. In the 4-week study, the sample group given carbonate apatite $+\mathrm{ZOE}$ scored quite high related to the formation of perfect dentinal bridge, which thickness was $>0.25 \mathrm{~mm}$, compared to the other sample groups. After 6 weeks, mean score decreased for each sample group. According to study on the effect of carbonate apatite on the repair of calvarial defects in rat bone, carbonate apatite had the same ability as hydroxyapatite to form new bone, but in the third week showed faster repair process. The sample group using calcium hydroxide showed that $70 \%$ had formed entirely dentinal bridge and $30 \%$ had covered more than half of the exposure area. This result is in line with another study regarding the response of human dental pulp after direct pulp capping using MTA and $\mathrm{Ca}(\mathrm{OH}) 2$, which showed the formation of dentinal bridge within 30 days calcium hydroxide showed better image of dentinal bridge compared to MTA. However on day 60, it showed the same results [31] The continuity of dentinal bridge which only covered more than half of the exposure area may be related to the uneven application of the material in the exposed area due to the difficulty of accessing the rat molars. The formation of dentinal bridge may appear to be irregular, atubular shape when compared to the surrounding unexposed dentin. The difference in thickness of dentinal bridge among the experimental groups is very likely to occur due to the different compositions of the three materials and the consistency of the treatment which cannot be controlled perfectly.
The ability of carbonate apatite to stimulate the formation of dentinal bridges can be correlated to the CO3Ap content consisting of $\mathrm{Ca} 2+$, $\mathrm{PO} 43-$, and $\mathrm{CO} 32-$ ions that function in the mineralization process.[32]

Based on the results, it was concluded that pure carbonate apatite paste material and carbonate apatite material mixed with ZOE could be used as an alternative to direct pulp capping treatment. These materials did not significantly differ in pulp inflammation or dentinal bridge formation with calcium hydroxide material.

\section{REFERENCES}

[1] American Academy of Pediatrics. Policy on Early Childhood Caries (ECC): classifications, consequences, and preventive strategies. J Pediatr Dent 2008; 37(6): 50-2.

[2] Ramayanti S, Purnakarya I. Peran makanan terhadap kejadian karies gigi. J Kes Mas 2013;7(2):89-93

[3] WHO. 2003. The World Oral Health Report. http:// www.who.int/oral health/media/en/orh-report03en.pdf. (accessed 14 October 2019)

[4] Badan Penelitian dan Pengembangan Kesehatan Kementerian Kesehatan RI. Riset Kesehatan Dasar (RISKESDAS) 2013. Jakarta 2013: 111.

[5] Octiara E, Tamba EA. Hubungan ekonomi keluarga dan pendidikan ibu dengan Early Childhood Caries (ECC) anak usia 12-36 bulan di Kecamatan Medan Denai. Dentika Dent J 2012; 17 (1): 78-82

[6] Torres MGG, Santos AS, Neves FS, Arriaga ML, Campos PFS, Crusoe-Rebello I. Assessment of enamel-dentin caries lesion detection using bitewing PSP digital images. J Appl Oral Sci 2011;19(5):4628.

[7] Hultquist AI, Bagesund M. Dentin caries risk indicators in 1-year-olds. A 2 years follow up study. Acta Odontologica Scandinavica 2016;74(8): 6139.

[8] Milcheva N, Kabaktchieva R, Gateva N. Direct pulp capping in treatment of reversible pulpitis in primary teeth-clinical protocol. J IMAB 2016; 22(4):1348-51. 
[9] Prijambodo SK. Stimulasi aktivitas fibroblas pulpa dengan pemberian TGF- $\beta 1$ sebagai bahan perawatan direct pulp capping. Disertasi. Surabaya: Program Pascasarjana Universitas Airlangga, 2005:153-6.

[10] AAPD. Guideline on pulp therapy for primary and immature permanent teeth. Reference Manual 2009; 32(6): 194-201.

[11] Alex G. Direct and indirect pulp capping: a brief history, material innovations, and clinical case report. Compendium 2018; 39(3):182-9.

[12] Mellisa, Hadriyanto W, Gunawan JA. Trioxide aggregate (MTA) studi pustaka. MIKGI 2011 Edisi Khusus: 86-91.

[13] Trilaksana AC. Dinamika kadar leptin dan fibronektin terhadap calcium hydroxide dan mineral trioxide aggregate sebagai bahan pulp capping. Disertasi. Makassar: Program Pascasarjana Universitas Hasanuddin, 2015: 19-51.

[14] Gandolvi MG, Siboni F, Botero T, Bossu M, Riccitiello F, Prati C. Calcium silicate and calcium hydroxide materials for pulp capping: biointeractivity, porosity, solubility, and bioactivity of current formulations. J Appl Biomater Funct Mater 2014; 13(1): 43-60.

[15] Sujlana A, Pannu PK. Direct pulp capping: a treatment options in primary teeth (Review). Pediatr Dent J 2017: 1-7.

[16] Aeinehchi M, Eslami B, Ghanbaria M, Saffar AS. Mineral trioxide aggregate (MTA) and calcium hydroxide as pulp-capping agents in human teeth: a preliminary report. Int Endod J 2002; 36:225-31.

[17] Kementerian Riset, Teknologi, dan Pendidikan Tinggi. Laporan Kinerja 2016. Jakarta 2016:87.

[18] Ardhiyanto HB. Peran hidroksiapatit sebagai bone graft dalam proses penyembuhan tulang. Stomatognatic J.K.G. Unej 2011;8(2):118-21.

[19] Ayukawa Y, Suzuki Y, Tsuru K, Koyano K, Ishikawa K. Histological comparison in rats between carbonate apatite fabricated from gypsum and sintered hydroxyapatite on bone remodelling. Biomed Research 2015:1-7.

[20] Wulansari I, Widiastuti MG, Prihartiningsih. Autotransplantasi gigi-gigi impaksi insisivus maksila kanan disertai kista dentigerous dengan penambahan graft kolagen karbonat apatit. Odonto Dent J 2018;5(1):9-17.

[21] PT Swayasa Prakarsa. GamaCha your bone regeneration scaffold. 25 Juni 2013. http://gamacha.info/profile (21 September 2018).
[22] Zakaria MN, Cahyanto A. An introduction to carbonate apatite as a biocompatible material in dentistry. Dalam: Zakaria MN. Pertemuan Ilmiah Tahunan 8, Prodi Kedokteran Gigi Unjani, 31 Maret 2017:81-4.

[23] Dianat O, Mashhadiabbas F, Ahangari Z, Saedi S, Motamedian SR. Histologic comparison of direct pulp capping of rat molars with MTA and different concentrations of Simvastatin gel. J Oral Sci. 2018;60(1):57-63

[24] Pudyani PS. Pengaruh kekurangan protein pre dan posnatal terhadap mineralisasi gigi. JKGUI 2001;8(2):54-9.

[25] Octiara E, 2016. Response immune in caries and role of odontoblast in immune response. Dentika Dent J, 19(1):83-8

[26] Fatimatuzzahro N, Haniastuti T, Handajani J. Respon inflamasi pulpa gigi tikus Sprague dawley setelah aplikasi bahan etsa ethylene tetraacetik acid 19\% dan asam fosfat 37\%. Dent J 2013;46(4):1-6.

[27] Sabir A, Sanusi VH. Perawatan pulp capping langsung pada gigi sulung. Dalam: Achmad MH Prosiding Pertemuan Ilmiah Nasional Kedokteran Gigi Anak V, 2011: 179-94.

[28] Salah M, Kataia MM, Kataia EM, Din EAE, Essa ME. Evaluation of egg shell powder as an experimental direct pulp capping material. Future Dent J 2018;5:1-5.

[29] Park YJ, Yang C, Jung IH, Lim HC, Lee YS, Jung UW, et al. Regeneration of rabbit calvarial defects using cells implanted nano-hydroxyapatite coated silk scaffold. Biomater Res.2015;19:1-10

[30] Njeh A, Uzunoglu E, Osorio HA, Simon S, Berdal A, Kellermann O, et al. Reactionary and reparative dentin formation after pulp capping: hydrogel vs dycal. Evidence based Endodontics 2016;1(3):1-9.

[31] Parolia A, Kundabala M, Rao NN, Acharya SR, Agrawal P, Mohan M, et al. A comparative histological analysis of human pulp following direct pulp capping with propolis, mineral trioxide aggregate and dycal. Australian Dent J 2010;55:59 64.

[32] Qureshi A, Soujanya E, Nandakumar, Pratapkumar, Sambashivarao. Recent advances in pulp capping materials: an overview. JCDR 2014;8(1):316-21. 